\title{
Defamiliarized family: The "Anak ng OFWs'"' emergent narratives \\ on mediated communication and parent-child relationships
}

Mary Jannette L. Pinzon

\begin{abstract}
The Overseas Filipino Workers (OFW) phenomenon has creatively deformed the traditional concept of the Filipino family. The Anak ng OFWs' narratives on parent-child relationships in a mediated setting show the transformative elements that usher the need to defamiliarize its traditional concept and reconfigure the Filipino family. Using the frameworks of Defamiliarization, Deconstruction and the idea of situated difference, the study illustrates how a defamiliarized perspective provides a negotiated fresh perspective of the Filipino family. Focus group discussions and interviews reveal findings that the "Anak ng OFWs" point to superficial, if not routine, conversations in online platforms, mediated relationships that are performed, and characterized by nakasanayan na [getting used to] perspective and the yearning for magkakasamang pamilya [a family that is together]. The study concludes that in a defamiliarized perspective, the situated difference is where OFW parents remain as the haligi [head of the family] and ilaw ng tahanan [pillar of the home] and where the essence of "family-ness" persists despite the cracks and fractures of the OFW family.
\end{abstract}

Keywords: Anak ng OFWs, defamiliarization theory, deconstruction theory, idea of situated difference, nakasanayan na, magkakasamang pamilya 


\section{Plaridel Open Access Policy Statement}

As a service to authors, contributors, and the community, Plaridel: A Philippine Journal of Communication, Media, and Society provides open access to all its content. To ensure that all articles are accessible to readers and researchers, these are available for viewing and download (except Early View) from the Plaridel journal website, provided that the journal is properly cited as the original source and that the downloaded content is not modified or used for commercial purposes. Plaridel, published by the University of the Philippines College of Mass Communication is licensed under Creative Commons Attribution-NonCommercial-NoDerivatives 4.0 International License (https://creativecommons.org/ licenses/by-nc-nd/4.0/legalcode).

\section{How to cite this article in APA}

Pinzon, M. J. L. (2021). Defamiliarized family: The "Anak ng OFWs"' emergent narratives on mediated communication and parent-child relationships. Plaridel, 18(2), 281-307. https://doi. org/10.52518/2021.18.2-04pnzon 


\section{Introduction}

The framework of the traditional Filipino family, or the way it has always been perceived has changed with the advent of labor migration in the Philippines. The family is the most important and most cherished institution in Philippine society as both F. Landa Jocano (1998) and Belen Medina (2015) affirm, but Maruja Asis (1994) writes that the family as a strong institution that has survived empires and republics now appears somewhat fragile against the tempest of international migration. This study interrogates the OFW parent-child mediated relationship, an important and foundational strand in everyday family life and relationship. It listens to the voices of the "Anak ng OFWs" and aims to determine their narratives on their perception of their family relationship and mediated communication transactions with their OFW parents. The study seeks to defamiliarize the issue of OFW parentchild communication in order to revitalize old meanings. In my review of literature I find that studies focus on the impact of the OFW phenomenon and the Filipino diaspora on the OFWs and their families. This author has not come across any study on defamiliarizing the traditional family as a new configuration. This study bridges that gap as it seeks to present a negotiated fresh understanding of the Filipino family. It seems that we no longer have familiar parameters. It seems that the Filipino family today is no longer the way we habitually construct it. Thus, this author interrogates how the OFW phenomenon disrupts our traditional view of the family, and, in so doing, makes strange the world of everyday perception. This author asks, how is connectedness in the Filipino family changing in the advent of the Filipino diaspora? Does the OFW phenomenon dissolve the family relationships and values, and destroy the family?

Ernest Burgess and Harvey Locke (1953, as cited in Segrin \& Flora, 2019) define family as a "unit of interacting personalities" (p. 22). Frederick Wamboldt and David Reiss (1989) support this transactional communication perspective as they view the family as a group of people who interact with a sense of home and group identity, with loyalty and emotional ties, and a shared experience of history and future. The parent-child relationship is the most primary intergenerational relationship in the family, and to some, the very relationship that defines a family (Segrin \& Flora, 2019). The Anak ng OFW define the family as "composed of individuals whom they love, for whom they care, whom they trust, and with whom they feel comfortable and secure" (Parrenas, 2006, p. 53). They are situated in this perceived overall family context where all past, present, and future communication transactions between them and their OFW parent/s affect their relationship and shape how they view themselves. 
Victor Shklovsky, (1965, as cited in Resseguie,1991) a Russian Formalist, coined the term defamiliarization, or ostranenie, which literally means "making strange." The theory tells that ordinarily, people's perception of the world is habitual, economical, and automatic (Resseguie, 1991; Mambrol, 2016). The meanings that hold become too familiar, so that they become desensitized: "Habitualization creates a desensitizing pall over the world, depriving us of actual experience. Habitualization devours works, clothes, furniture, one's wife, and the fear of war" (Resseguie, 1991, p. 137).

There is a need to revitalize old meanings into something new. Defamiliarize old, habitual meanings so that the "familiar that blurs everyday perception" is stripped away, and the actors are awakened from the "lethargy of the habitual" (Resseguie, 1991, p. 137).

Shklovsky's (1965, as cited in Ressiguie, 1991) concept ofdefamiliarization is useful in studying the Filipino family because it helps define its familyness, or the qualities that make it family. As in literary analyses, the object of critical investigation is not literature itself, but the literariness of an artistic work, that is the qualities that make them literary. Shklovsky emphasized that art imparts "the sensation of things as they are perceived and not as they are known. It is a way of experiencing the artfulness of an object; the object is not important" (Ressiguie, 1991, p. 137). In this study, this author interrogates the Filipino family as a cultural text, situated in an entirely new ethnoscape, where one is able to see its family-ness, or the qualities that define it as family.

Defamiliarization is an essential link between the reader and the literary text. As a reader of the Filipino family, one brings their own knowledge of familiar conventions. They possess what Iser Wolfgang (1978, as cited in Resseguie, 1991) calls a reader's repertoire that may be literary, social, cultural, religious, or political, etc.. The Filipino family, considered as the cultural text, places familiar elements into new configurations for the reader to assemble. The OFW phenomenon ushers in these new configurations, marks out new and unfamiliar territory that the reader makes concrete the potentiality of the text, that is, the Filipino family. In the process of actualization, the reader's repertoire is made to seem strange. When one interrogates the present realities, seemingly different from the origins of an OFW family, they defamiliarize the familiar.

Resseguie (1991) defines defamiliarization as "the creative distorting of a familiar object or a routine convention to make it appear strange and unfamiliar" (p. 137). One's normal, everyday perception of the traditional Filipino family, since it is habitual and automatic, recognizes it as a mere silhouette and they fail to see it as it truly is, making stale their awareness of the world. 
In the study of the Filipino family as a cultural text, this author finds useful and supportive the aspect of Jacques Derrida's (1976) Deconstruction Theory that emphasizes the incompleteness of the texts. Derrida shows that any text can be read as saying something quite different from what it appears to be saying, and that it may be read as saying several alternative meanings. He argues that there are many possible interpretations of any given text.

The family as a cultural text can be read or interpreted with as many potential reading as there are readers for it. As a cultural text, one recognizes the family as possessing a particular type of behavior seen as a relatively coherent whole, having internal boundaries established by its text-producing actors and situated in a particular context that is the OFW Phenomenon.

As a deconstructionist, Derrida (1976) believes that there are absences within any text. The point of deconstruction is to show where something is omitted, the cracks and fractures, not because of the blindness of the author or that the critic is smarter or better, but because that is the way things are.

All texts are context sensitive, meaning every text is influenced by the context within which it appears. Therefore, some contextual information must be provided in discussing the text (Leeds-Hurwitz, 2002). The OFW family situates itself in the context of the OFW phenomenon representing an ethnoscape, the landscapes of moving persons, of shifting histories and spatial fields (Appadurai, 1997). The OFW phenomenon ushers in what Arjun Appadurai (1997) calls an idea of situated difference in relation to something local, embodied, and significant. This author would translate Appadurai's idea of situated difference to what Derrida (1976) calls meaning shifts, a result of fundamental difference that undermines every necessary binary structure of conceptual thought, and in this study, this author refers to the traditional Filipino family and the OFW family. This difference is the same difference that is seen when the Filipino family is interrogated in light of present realities, that is, as I mentioned earlier, when one defamiliarizes the familiar. It is this difference that brings the meaning shifts and which continually show differentially what was said and how it is said about the Filipino family and reattaches in new combinations or configurations. Filipino family has taken different directions and made new meanings as it faces the changes and challenges of the times. In this study of the Filipino family as a cultural text, Derrida's invite to go deep is applicable and pragmatic, agreeing with him that there will always be something hiding behind an already existing text or the so-called neglected corners of the text (Internet Encyclopedia of Philosophy, 2018).

As the study takes up defamiliarization of the Filipino family by investigating how the OFW phenomenon has creatively deformed the 
familiar context of a traditional Filipino family, this author recognizes the importance of going beyond what is habitual, economical, and automatic, consider the cracks and fractures and keeping an open mind to the many possible interpretations of the neglected corners of the cultural text, that is the Filipino family.

\section{Research Problem and Aims}

This study recognizes the need to estrange or defamiliarize to see things anew, to renew our perspective of what and how family is, as in the literariness of a work. This leads to the question: "how does one defamiliarize the traditional concept of the Filipino family, reintroduce the Filipino family in the context of the OFW phenomenon and the Filipino diaspora that reconfigure the Filipino family?" This study focuses on the heart of family life: family communication, specifically, the interactions between OFW Parent and their "Anak" in a mediated setting. This study focuses on following research questions:

1. What are the narratives of the Anak ng OFWs on their mediated communication with their OFW parents?

2. How do the Anak ng OFWs view their relationships with their OFW parents?

3. How do we defamiliarize the issue of OFW parent-child relationship and communication in the mediated setting?

This paper would like to contribute to a new, negotiated understanding of the Filipino family. This paper adds to the discussion on how connectedness in the Filipino family takes on a different perspective, veering away from the traditional view of the Filipino family.

\section{Literature Review}

The narrative of the traditional Filipino family begins with familiar institutional labels - the father, as the haligi ng tahanan [head of the family], works to provide for the family; the mother, as the ilaw ng tahanan [pillar of the home], is expected to look after the home and the children; the children, as biyaya $n g$ Diyos [gifts from God] are expected to be obedient and loyal to their parents. Children bring kaligayahan [happiness]. Socialization practices in the Filipino family and the care of children are characterized by pangangalaga [care], pag-aaruga [nurture], pananagutan[responsibility], and pagkamatapat [filial piety] (Jocano, 1998). If Anak ng OFWs are truly what Jocano theorized as the biyaya ng Diyos and sources of kaligayahan, how can their OFW parents make them feel abandoned by leaving them behind to work abroad (Asis \& Marave, 2013; Jocano, 1998; Reyes, 2008). 
Is this not, in fact, care drain, a consequence of the OFW phenomenon on the Filipino family or the after-different-than before engendered by the Filipino diaspora? Johanne Jazmin Tan Jabines (2018), the English Speaking Union champion in 2018, resonated this reality in her winning speech,"It is an ironic fact of a migrant's life that to show someone you love them, you often have to leave" (p 2).

In the context of a changing Philippine society, Belen Medina (2015) asserts that the Filipino family structures and values makes traditional norms increasingly inadequate and sometimes conflicts with new modes of conduct. The rapid social change may bring about rifts between spouses, parents and their children, marital tensions and problematic situations among the children. Medina, however, claims that the family as a social institution is resilient and has the ability to adapt and change in the face of social and cultural changes. Richard Gelles (1995) affirms the family is not dying, but rather is changing, evolving, and adapting.

Migration is rarely an isolated decision pursued by individual actors rather it is a process that involves a range of kin and other agents. As Larsen et al. (2006, as cited in Morley, 2017) puts it, most "people's biographies and travel patterns are relational, connected, and embedded, rather than individualized" (p. 142), more so in the OFW family narrative, where decisions such as going abroad or becoming an OFW, is undeniably, a family decision. Work migration decisions were basically household decisions and that these were justified because the move was deemed beneficial to the family members (Asis \& Marave, 2013; Bautista \& Tamayo, 2020; Hall et al., 2019).

Education for their children is the most frequently cited reason for OFW parents who decided work abroad. Among the major spending priorities of migrant remittances by families is the children's education. It was even more than what was set apart as capital for business, purchase of a house and lot, and cash savings all combined. The decision to go abroad is legitimized by a need or pangangailangan (Asis \& Marave, 2013; Hall et al., 2019; Taylor, et al., 2012). OFW adult children accept and understand that their parents work overseas to build their family's future. They respect their parents' decision to work abroad [paggalang] for their welfare and future, they have a debt of gratitude [utang na loob], and the concern [pagmamalasakit]) for their parents' safety overseas.

In recent years, however, studies among middle-class families show that reasons for migration have gone beyond mere survival to the desire for more mobility and adventure. Filipino migrants in Italy, for example, were gainfully employed mainly in the service sector, prior to their departure, and were not "surplus" labor. Some OFWs expressed less "altruistic" reasons such 
as "to see the world" and "emulate friends and relatives abroad who appear glamorously modern and westernized". Overseas employment for some has been a path toward social mobility and personal growth. Household income has become only secondary motivation (Tacoli, 1996). Employment abroad has been framed as a means to provide self-fulfillment rather than simply jobs or money (Bernardo et al., 2018). There are migrants who expressed general dissatisfaction with life in the Philippines, from feeling that one's career is at a dead end to familial relationship problems (Bernardo et al., 2018; Tacoli, 1996). However, in the overall OFW phenomenon experience, when asked what sustains the OFW parents in the challenging landscape of overseas work, the OFWs in the Middle East represent what OFWs commonly say, "Iniisip ko lagi para sa pamilya ko ito" [I always think that this is for my family]: their family and children are buttresses in the OFWs and migrants' life abroad. Perhaps these are the OFWs to whom labor migration was no longer an option but meant, remittances, otherwise framed as a necessity.

Research work spearheaded by Scalibrini Migration Center (2004), presented the results of a 2003 nationwide research on young children and families left behind. This study showed that the departure of mother or both parents clearly reconfigured caregiving and provider roles. Family relationships remain relatively close, but in migrant families these are maintained not by presence but by constant communication using what technology provided today cell phones, phone calls, texting, Skype online chatting, and other forms of mediated communication. A United Nations Children's Fund study reports that although the absence of either or both parents can be bridged by mediated communication to make their presence felt by their children, it is not able to replace the emotional bond forged by daily face-to-face interactions. While there is communication between the OFW parents and the children, the study reports that it probably lacks the depth that genuine and effective parenting required. There is evidence that this communication becomes less effective as the younger children are considered. The study highlights that the real challenge is how families and other relevant institutions can guide and support the children as they tread the transition into adolescence (UNICEF, 2008). .

Racidon Bernarte et al. (2015) write about mediated communication tools that are used in OFW family communication: snail mail, voice tape, telephone, and mobile phone while computer-mediated communication tools are the use of internet or computers. Almond Pilar Aguila (2008) writes that the OFW and their family have no alternative preference but to depend on computer-mediated communication tools to have persistent communication and to maintain intimacy with each other. This transactional perspective characterizes feelings of family identity, emotional ties, intimacy, 
interdependence, commitment, and an ongoing history and future (Segrin \& Flora, 2019).

\section{Methods and Procedures}

This qualitative study takes on a constructivist approach. It utilizes Grounded Theory-inspired principles that included Theoretical Sampling (Corbin \& Strauss, 1990), Theoretical Saturation and Coding (Glaser \& Strauss, 1967) to inform my work. This author is not after the measurements rather after the personal and social meanings constructed by the Anak ng OFWs based on their experiences and reflections and as seen through the emergent narratives they related.

Anak ng OFWS, with ages 18-25 years old, city-based, and undergraduate students participated in this study. The particular age range was chosen because the informants are expected to already possess the ability to express themselves. Besides, the length of years as an OFW family or being an Anak also provided ample life experiences that helped validate their perspectives about themselves and their family life. Pseudonyms were provided to protect the privacy of the informants. Their participation was voluntary. Their informed consent was obtained. Two focus group discussions were conducted with six and seven participants in each, respectively. One-onone interviews were conducted with a separate set of respondents. Both English and Tagalog languages were used to allow the respondents to express themselves freely and comfortably. Open-ended questions and follow-up questions were used to encourage narrativization, to further probe their answers and allow respondents to construct their answers in ways they found meaningful. In-depth interviews using a preliminary pool of five respondents were conducted. Oral first-person accounts of experiences or what Labov and Waletzky (1967) called natural narratives were considered. After the data of the first of interview was analyzed, this author decided to conduct a second set of five interviews to further support the data. This study engaged in Theoretical Sampling a process of continually collecting and analyzing data until the comparative process reaches a point of saturation, the point at which there are no new ideas or insights emerging from the data (Glaser \& Strauss, 1967). After the second set of interviews, this author has seen a strong repetition of core narratives or themes that I have observed and were articulated. Both the FGDs and the interviews focused on the respondents' experiences and their growing up years as Anak ng OFWs. I analyzed the data with the following three levels of coding. First is Open Coding where I divided into similar groupings and formed preliminary categories of information about the research questions and theory. Second is the Axial Coding where the categories were identified 
into groups by themes or core narratives that should provide ways of seeing and understanding the issues and theory brought about by the study. Third is Selective Coding where I organized and integrated the categories and recurrent themes that articulated a coherent and unified understanding of the issues relevant to the study. I observed that respondents had some conflicting responses concerning parent-child communication and relationship with their OFW parents. The different insights were taken note of, although it is beyond the study to probe further the contexts that informed their differential understanding of their situation as Anak ng OFWs. I also took note of the clustered responses in the FGDs where respondents agreed or disagreed concerning certain issues that molded their life orientations of the Anak ng OFWs. The data collected through these codes assisted in revisiting the framework and in interrogating the OFW family on the basis of the interaction between the concepts from the framework and the codes.

\section{Results and Discussion}

\section{Anak ng OFWs on Mediated Communication with their OFW Parents}

The OFWs no longer live just in one place, but simultaneously inhabit a range of virtual elsewheres (Meyrowitz, 1986). There is a newly configured communicational space given the variety of virtual elsewheres where OFW parents now make themselves present at home while being in a realm of what David Morley (2017) termed "technological uncanny". Rowan Wilken (2011) rightly describes it as seeing the overlapping or intertwining of the virtual and the actual as the OFW parent and the safely-at-home Anak ng OFWs engage simultaneously in different communicative modalities to keep connected. The OFW families found various ways to socialize at a distance as either a regular or intermittent practice.

\section{Mothers as Bridges}

The Anak ng OFWs in the Focus Group Discussions shared similar stories of using social media to stay in touch with their OFW parents and vice-versa. They used Friendster, WeChat, Facebook/Messenger and Skype. Their mothers, whether OFW or stay at home Moms were the ones who would usually send messages. They also did it more often, as compared to their OFW fathers. Mothers took the initiative to communicate and served as the bridges of messages in the family. Emily recalled, how as a child, she would wake up so early to chat with her dad online, but that her mother would chat with her OFW Dad first, only afterwards the children took turns to send their messages to him. Ben always received messages through his mother because his OFW dad never talked to him directly. Dad called every Friday but during his growing up years, Mom was the bridge between them. 
Robert's image of his dad was the man beside his mom on a wedding picture or the wedding video. It did not help that when his father called home, he would talk only to his mom. Robert described his relationship with his dad as not normal because they have been used to not communicating: "....wala talaga kaming communication ng Dad ko...nakasanayan na na hindi kami nag-uusap" [my dad and I do not communicate at all....we have been used to that].

\section{Superficial Online Conversations}

The narratives of the Anak ng OFWs described their online conversations with their OFW parents as generally superficial. Pangungumusta or asking about how they are doing in their studies, the weather, high grades, travels, and what would make their parents proud. Before Facebook Messenger was available, Julia's father made regular long distance calls. He made sure that his family was home when he called and talked to everyone. Phone conversations ended with loving words such as "bye Daddy, love you, ingat, take care" but it was simply kumustahan. The exchanges mostly revolved around school and everyday tasks at home. Julia did inform her dad about her sad moments but through messages on Facebook, not directly. Marian and her dad would use the webcam to talk to each other but as the years went on, they would just chat online once in a while, mostly to exchange pleasantries or mangungumusta lang. Mae's OFW dad initiated video chats or Facetime about 3 times a week but conversed mostly with her mother. Mae felt disconnected with dad because besides the short mediated exchanges and only about school, he did not seem to listen sincerely, mindlessly changed the topic and interrupted Mae from sharing her own stories.

\section{Shallow Relationships and Mediated Performance}

As a result of superficial mediated conversations with their OFW parents, the Anak ng OFWs felt that their relationship with their parents was shallow. Janna was connected with her mom through WeChat but felt awkward and was hesitant to disclose her personal issues. She found it difficult to discuss intimate and sensitive problems with her mom. If Janna would rather sweep her problems under the rug, Jenny would rather be self-reliant or cry alone than disclose to OFW parents. Rico would rather confide with his siblings and friends about emotional problems. There was no sharing of personal matters between Marge and her dad despite his expressions of love and concern for her. As for Erin, the superficial relationship created the need of her dad's comfort and assurance during the difficult times. 
One thing seemed to lead to another. This shallow relationship described by the Anak ng OFWs with their parent/s made them communicate messages that did not necessarily present the realities back home.

The Anak ng OFWs reported the need to perform to please their OFW fathers. Performance meant sending online messages and choosing what to disclose or not to the OFW parent. Gabbi revealed only what would please her father who was based in Saudi Arabia. She was always ready with her funny and happy stories, such as her academic accomplishments, whenever he called home but never related problems to him. Matt recalled being required by his mother to send to dad a text message once a day. This expected daily ritual became an obligation to perform and the messages became less personalized.

Their grandmothers or mothers who looked after them instructed them to communicate only favorable news, not to broach any topic that may add worry or stress to their OFW parents: “...happy heart lang dapat... pasayahin sila kasi ang layo nila...put that mask on..." ["keep happy hearts... make them happy because they are far...put that mask on...]

They would not be vulnerable or cry or share sad details about themselves. The communication between them and their OFW parents was expected to provide a more connected relationship and strengthen the familial bond. But because they could not share intimate and personal issues in this mediated context, they felt distant from their OFW parent/s. They felt the need to work things out and cope with their problems by themselves rather than burden their OFW parent/s.

The Anak ng OFWs eventually found out that their OFW parents, on their end, were not disclosing their problems to them either. They generally talked about their happy experiences on the job, good times and would rather have tuksuhan or lokohan at asaran [fooling around or joking around]. When their parents had marital problems or when they got sick, informants learned about it through relatives. This made Rico depressed but somehow understood how parents did not want their children to worry. When Rayven's father lost his job in Dubai, the family knew about it only when he had found a new job. They did not know the struggles father experienced during the lull period. Gabbi and her family were not informed about dad's deteriorating health while in Saudi Arabia. They did not expect him to be very ill and to pass on not long after he returned home.

The non-disclosures, almost a given situation, were common stories among Anak ng OFWs. Cristina Liamzon (2010) noted that they had learned to hide their real feelings to avoid worrying their parents. The end-result of this type of mediated communication dynamics was not only a sense of 
disconnect but also an uncomfortable feeling of being kept out-of-the-loop despite being family.

A significant element in the Anak ng OFWs' life orientation was that they were either at a tender age when their OFW fathers left for work abroad or that their fathers were gone before they were born. Julia could not recall knowing her dad in her early years. Marian felt there was a stranger in their house when Dad came home and felt so awkward when he hugged her. Mae was 6 years old when her father, a seafarer, left. She did not feel close to him: "pag nag-uusap po kami parang di po niya ako kilala, hindi ko rin po siya kakilala" [when we talk he does not seem to know me nor do I know him]. Emily asked how she could feel being left-behind when in the first place there was no relationship there. The long years of separation between the OFWs and their "Anak" breed unfamiliarity and lack of meaningful bond in what was called ironically a "distant love affair" (Abenir, 2010; Liamzon, 2010; Tanalega, 2002). When Gabbi was in grade school her father existed only in photographs. He came home every four years: “...tinatanong nung classmate ko nung Grade 3. Umuwi ako, Ma, sino ba talaga ang papa ko? [my classmate in Grade 3 asked about my father. I went home to ask my mom who my dad really was?)]. They were blood relatives and yet, felt like strangers to each other. The Anak ng OFWs longed for relationship with their distant OFW fathers. They preferred them to be immediate and present but recognized that their absence was engendered by a family need. As a result, the Anak ng OFWs brushed aside their longing for in-depth communication and relationship. Instead, they created unique ways to survive and cope. Beth felt left-behind but held on to the promise that her father was coming back to make things right at home.

The common narrative among the respondents showed superficial mediated communication exchanges between them and their OFW parents. These experiences, coupled with physical absence and non-immediacy led to barriers in communication and distant relationship, especially with their OFW fathers.

\section{Anak ng OFWs on Relationships with OFW Parents}

\section{Nakasanayan na}

In the absence of their OFW parent/s, the Anak ng OFWs created spaces for the little family. Sylvia Basas Concepcion (1998) called it a virtual or imagined household that had come to exist when the OFWs left and children were either left with extended kin or distributed among relatives. They constructed a unique framework of a family structure suitable to their situation, comforting and practicable for survival and made their lives meaningful. As what Concepcion (1998) and Medina (2015) wrote, they did 
not need to be co-residential or live together in one place to make or be a family. They did not always have to share eating arrangements as they used to but they could share chores and tasks, assume new responsibilities such as the tagasalo [one who is assigned to take over tasks or voluntarily takes on the responsibility] as ate [older sister] and kuya [older brother], and to give emotional and moral support to each other. Emily described how her siblings and herself liked to stay at home and always be near their mother, doing things together in the kitchen, simply being together in their living room or bedroom. This arrangement gave them a lot of warmth and comfort in the absence of their OFW father. They let their sibling lives revolve around each other and their mother. Ben recalled how his mother made sure that she stayed home most of the time when his OFW father came home, so they could maximize their family time. To the Anak ng OFWs, their parent's homecoming were extraordinary days they called fiesta [celebration], characterized by balikbayan boxes (care packages that contain gifts and things for everyday use sent by OFWs to their families back home), family travels and family time. It was celebratory, but when their parents were gone, the anak described it as going back to what was "ordinary," or "back to normal", the everyday humdrum of life. The Anak found themselves not missing their OFW parents for long, only for two days to two weeks, they described. Then the Anak settled down: "next year ulit" [til next year]. This was the kind of life they have been used to. In other words, in their own words: "nakasanayan na" [getting used to].

\section{Magkakasamang Pamilya}

The Anak ng OFWs recognized the pangangailangan [necessities] that their parents needed to meet for the family. They appreciated how financial needs were provided with work abroad. But to them for the family to stay together while making ends meet was a strong desire. Marge described how they could afford private schools but regretted that her father who worked in Riyadh was never home: "every birthday, ilang pasko na ba, ilang New Year na, sa graduation ko, hindi siya kasama" [every birthday, how many Christmases, New Year celebration, and on my graduation, he was never with me]. Gabbie had the same sentiment that her father was never home for her birthday or attend her graduation to pin her medals. Ally expressed the longing for the family to be together especially during Christmas time. Marge echoed this desire because she felt detached despite having online conversations with both parents in Qatar. Marge and Mae felt that family connectedness gradually thinned out because parents were away. They expressed their desire for OFW parents to stay home for good. Julia, Matt, and Beth pointed out the small gestures of love when their parents were 
present, how they took them to school and picked them up, and for Beth, how they watched her as an athlete.

During their growing up years, the Anak ng OFWs would be envious every Family Day when they see other families complete or families are out together in the church, malls, or restaurants: “...tuwing nagche church po ako may mga pamilya na sama-sama...ako po nasa isang corner lang po nakikinig mag-isa...di rin po ako gumagala kasi naiinggit po ako sa mga tao na kasama nila pamilya nila..." [...everytime I go to church and see families together...I sit in one corner listening all by myself...I also do not go around because I feel envious of people who are with their families].

Being apart from their OFW parents made them appreciate much more the joys of magkakasamang pamilya: "...alam mo yung pain na wala sila ... alam mo rin ang joy na kasama sila" [you know the pain of not having them around...you also know the joy of being with them].

However, the informants narrativized what Reismann (1993) described as a breach between the ideal and real. With all the expressed desire for their family togetherness, it was ironical that they would even consider following the footsteps of their OFW parents to work abroad. Julius, for example, opined: "Gusto ko po talagang mag abroad like my Dad ... tapos narealize ko, paano nga pala ang magiging future na anak ko" [I really like to go abroad like my dad...then I realized how would the future of my child be].

The Anak ng OFWs weighed all the pros and cons, including the economic benefits of having OFW parents. They recognized the exigency that led to the Filipino diaspora but when given the choice they would rather keep their family intact. They considered the impact of this decision on the future of their children, the way it has affected them. Rico stated with all conviction, "You build a family to be together. You don't build a family to be separated. If I we're to raise a family, dapat together" [If I were to raise a family, we should be together].

They might have considered to work abroad but to take the family with them was nonnegotiable. The Anak ng OFWs, for better or for worse, might have accepted life as it was for them. But Ben summarized their desire: "hinahanap din ang pagmamahal ng isang buong pamilya" [we seek to have the love of a complete family ]

To the Anak ng OFWs, the efforts to stay connected through mediated modes did not substitute such longing in their hearts.

\section{Defamiliarized Filipino family in a mediated setting}

As the OFW parents arrived at a new place, removed from their habitual, natural space in their home country, they carried with them their 
culture. In fact, this relocation made them more sensitive to the cultural assumptions that were taken for granted and could be absent in their host country (Moores \& Metykova, 2010). Thus, they recreated a sense of the familiar or a sense of home as they tried to fulfil their parental roles while being away. They held onto what they perceived to be traditional beliefs and practices, and yet, enacted them in ways not as they are known, not as they have habitually experienced, that is, defamiliarizing the familiar, creating new configurations in their OFW family and their familial relationships.

Through mediated communication, OFW parents and children have tried to remain connected. However, as Morely (2017) noted, mediated communication may have made absences virtually present across the spatial distance but OFWs could only continue to exist for their Anak in a relatively insubstantial or virtual form and unable to participate in the ongoing daily lives of their families. Jennifer Light (2001) posited that virtual technology is offered as a technological band-aid, a cheaper alternative to improve physical access to particular locations but that virtuality itself confers second-class forms of interaction. Mediated communication has enabled the OFWs to maintain ongoing virtual presences in different locations but that the Anak ng OFWs described the inefficiency of virtual interaction in parent-child communication: superficial, if not routine. While the UNICEF report in 2008 suggested the lack of depth, the Anak ng OFWs pointed out the lack of intimacy and closeness. Communication, indeed, cannot be reduced to instrumental functionality (Morley, 2017). Virtual forms cannot substitute the get- together, the seemingly irrelevant small talk, the informal banter, the intermittent face-to-face interactions.

Furthermore, Morley wrote that when copresent conversation is transmuted into a mediated form of communication, a thinning of the communication medium strips away more and more context allowing more potential misunderstanding. The more closely a medium can replicate faceto-face interaction the nearer it achieves thickness of the communication content available to the participants of the communication situation. The Anak ng OFWs indicated that they and their OFW parents used Skype, WeChat and Messenger. Albeit these modalities are closer to face-toface interaction, they are still limited. They impose unnatural formality in conversational turn-taking as a result of slow transmission. The fluidity of the conversational flow can also be hampered by unclear rules of turn-taking. It is therefore hardly surprising that the Anak felt not genuinely connected with their OFW parents. It did not help that the informants shared only the good news. Their OFW parents also did not disclose important details to their Anak. Bad news are said to be better spoken in a face-to-face 
interaction, if not to be made worse. In fact, face-to-face interaction would be used as a communicative strategy.

It seems that technology and balikbayan boxes could not compensate nor take the place of physical presence required in effective parenting of OFW parents and in building close relationships and trust between them and their Anak. Parents' role to provide for their children also involves their presence with them. Rico admitted that his needs as a varsity player could not be amply supplied without the financial support of his OFW parents: "Sinusuportahan naman nila ako it's just that wala sila dito physically" [They supported me except that they were not with me physically].

The missing link cannot be denied. The study showed that the Anak ng OFWs appreciated how their fathers provided well for them and the social status of having OFW parents, but physical presence is of great significance.

\section{The mediated setting as a situated difference}

In reality, there was a relationship despite all the odds and differences. Parents may not be at home nor were immediate to their children in their time of need but sent needed financial support that sustained these Anak in their growing up years. As OFW parents, they remained haligi and ilaw ng tahanan. The narratives of the Anak ng OFWs showed how they suffered the lack of pag-aaruga [nurture] by their OFW parents in the physical absence of their OFW mothers or fathers, but perhaps this is what Appadurai called the idea of situated difference where despite all the said-to-be downsides of the OFW phenomenon where families break-up, couples separate, or children grow up with no parents to guide them, the OFW parents showed pag-aaruga in their own way, from afar.

For Jenny, the sense of immediacy was rather strong as she perceived the presence of her OFW Dad as really close: "nandiyan lang si Papa, katabi ko" [he is just here, beside me]. Jenny created that psychological space for her father to be virtually present with her. To Beth, her father may have left unfinished projects at home but his initiatives when at home showed that though apart, he remained the general handyman of the household. The family situation may not be the same but tatay [father or dad] carries on his traditional role albeit practiced in a different way. The OFW parents may not have been near to watch their children grow but as for Lagpao, one of the many migrant women, described in Clement Camposano's (2012) study, the balikbayan box or care packages have become something of a symbol of long-distance mothering. Morley (2017) wrote that transnational relationships are often embodied in the food and gifts shuffled back and forward across borders. They represented a whole, new way of inculcating family values and strategies to develop their children's potentials in dealing 
with tough times. Besides the balikbayan boxes, the OFW parents would call home regularly. These were some gestures or expressions of their pagaaruga.

Miller and Madianou (2012), in their journal article, expressed their pragmatic view of the extent that mediated communication may substitute for physical presence in multisite households, and that polymedia becomes inextricably linked with the interpersonal relationships between the OFW parents and their Anak. As they deal with family separation and their leftbehind children for long periods, they avail of mediated communication to maintain family connectedness. Polymedia can be considered as a "defamiliarizing" apparatus as OFWs use various forms of mediated communication to create a communicative environment to invent forms of virtual parenting. However, Morley (2017) cited the limitation of the virtual form of proximity where cases of real time proximity achievable via telepresence created profound psychic crises. He gave the example of an OFW mother who virtually attended the birthday celebration at home of her Anak but tragically, the connection was suddenly cut as she was about to blow her candles. Based on this work it can be argued that electronically transmitted parental messages can never be totally satisfactory substitutes for "being there."

And yet, John Urry (2007) is cautious to acknowledge that, even as the continuing importance of co-present interaction is fundamental and primordial mode of sociality, we need to recognize that in a networked society, a metaphysics of presence focused on primarily face-to-face interaction in proximate communities, may in itself be inadequate. In Morley's (2017) language, the ideal of direct communication is a metaphysical illusion. Urry (2007) suggests that there is a need to transcend the dichotomy and recognize that "human agency and social networks are complexly interwoven with mobile phones, email and means of corporeal movement and co-present and distant communication increasingly intermingle" (pp.177.

In other words, we defamiliarize the habitual and familiar and seek a more pragmatic approach and avoid any idealized view of authentic face-toface interaction. The OFWs and their Anak transcended the differences and settled for the pragmatic approach of maximizing provisions of technology despite their limitations. Miller and Madianou (2012) described it as a new relationship between the social and the technological, transforming interpersonal relationship at a distance. From this perspective, the mediated exchange could be seen pragmatically as a useful element in the repertoire of communicative practices, not necessarily to debase rather to seek the essence of family in the OFW parent and Anak relationship within the 
realities of the Filipino diaspora and the OFW phenomenon. That is the way things are.

The essence of family-ness is different from what is traditionally known and yet it is that kind of family set-up that is simply nakasanayan $n a$ [getting used to], the kind of family that Gelles (1995) described as not dying, but rather is changing, evolving, and adapting. The Anak ng OFWs recounted their past events and actions that showed the nakasanayan na attitude. They have constructed their lives cognizant of the after-differentfrom-before effect of the OFW phenomenon. Like all social actors, their narratives were inevitably self-representation, how they wanted to be known as Anak ng OFWs. Despite the reality of a cultural context where nakasanayan na attitude was real, they reflected the values of what was important. The institution of family is here to stay. The elements of familyness, of pamilyang magkakasama [family togetherness], and the cultural values in family relationships are still there albeit the way of doing them, expressing them changed (Father Rex Manasan, personal communication, February 23, 2017).

The present realities of the OFW family make us appropriate new perspectives of the Filipino family as we defamiliarize the familiar. The OFW phenomenon had made strange our usual, prosaic perspective of the Filipino family. We find the meaning shifts that Derrida described or the idea of situated of difference that Appadurai coined. Fathers had not stayed home as haligi ng tahanan, but they maintained and performed such roles even when away from family. All the Anak ng OFWs appreciated the fact that, no matter what problems there were in their family life and relationships, their OFW fathers were present by providing well for the family.

Gabbie appreciated that her school allowance always came on time. They also related how their OFW fathers expressed their love to them and how much they missed being home. Marge felt how her father fought back his tears when they talked online.

Mothers could not stay at home as ilaw ng tahanan, but they continued to be ilaw from a distance, remained connected through online messages, holding the reins of the home from a distance by sending home care packages or balikbayan boxes (Santos, 2015; Camposano, 2012). Being OFW parents meant working out consistent family communication lines, maximizing mediated communication. It meant raising their Anak from a distance through remittances and balikbayan boxes. Carolyn Sobritchea (2007) described it as doble sakripisyo [double sacrifice], that is, being a breadwinner and a homemaker at the same time. But that was how it was, they were family. 
The Anak ng OFWs interacted with a new reality, necessary but productive, glued together into something different, something strange in their family life, and yet, nakasanayan na. In the OFW family narrative, they were the distant, estranged left behind children but they have evolved to be strengthened individuals with their unique self-identity.

Gabbie described her family as never complete but she learned to accept this incomplete family situation: nasanay na ako [I got used to it], with a sense of freedom. To her, what was ordinary was having her Muslim Dad depart and she with her mother and sister could revert back to their Christian way of life. The time of homecoming for their OFW parents was the "extraordinary" family time. Jenny appreciated the many gifts or pasalubong [a gift given by one who arrives from a trip] brought by her parents, but what was most precious to her was that her parents were home. The family was in a celebratory mood because they were all home, complete and together. This was their foremost desire, the magkakasamang pamilya [a family that is together].

The Anak ng OFWs enjoyed the extraordinary family time of magkakasamang pamilya, with their OFW parent/s. But they braced for the coming months, when vacation time ended and it was time to be separated again miles apart. They had to change their mindsets to go back to the "ordinary" days, to go "back to normal," when the home quiets down to everyday routine. It is the family situation that the Anak respondents described as nakasanayan na: a time that they have all learned to accept and live with as Anak ng OFWs.

The OFW family as a cultural text and situated in the context of the OFW phenomenon possessed this particular behavior of nakasanayan na; its boundaries drawn by its text-producing members; its cracks and fractures taken as normal elements of newly-created configurations of the family.

Erin thought that it was a normal occurrence for parents to be separated from their children or that they would be away as OFWs. Rico believed this was life! Thus, he and his siblings have become the little family, on their own, without their parents. To Mae, waking up to find her daddy's bed empty became a routine. To her, nakasanayan na meant getting so used to having his seaman father away that she could take for granted not knowing where he was at the moment: "Hala! Hindi ko po alam kung nasaan siya ... nasa ano po yata siya ... nasa Spain ganun" [Oh my! I do not know where he is...I think he is in... Spain that's it], Mae retorted. She would miss him, but eventually, his absence became what was normal at home: "parang pag nagtagal normal na lang" [as time goes by, it becomes normal]. Gabbie simply stayed home with her brother and mom while Lyn had to settle being 
looked after by her uncle and aunt. Whatever it became, it was the kind of "family-ness," the family set-up that they accepted.

These illustrate a new perspective, a defamiliarized view of the family in a situated difference where a family once perceived as whole only when together, but now as Derrida (1976) puts it, that is the way things are. The Filipino family takes on new meanings shifting from what is traditionally known, created in the advent of the OFW phenomenon. These circumstances engendered by desire and need led to these cracks and fractures of the OFW family. The Anak ng OFWs recognized what was absent. They saw the kakulangan [what was lacking] in the absence of their OFW parents and would want to intentionally avoid pagkukulang [shortcoming] on their own children. Marian wistfully described a kakulangan as she opted not to be an OFW and leave her own family: "Ayoko po kaseng maramdaman ng anak ko po na parang may kulang po" [I do not like my child to feel that there is something wanting].

Julia put words into this wanting inner space when she was asked if she would follow the footsteps of her OFW Dad, she decided:"Hindi ko kaya... parang maisip mo rin na baka may pagkukulang ako..." [I can't do it...I would think that maybe I will miss something]. To which Gabbie echoed “...never akong naging contented... ang laki ng butas na di napunan" [I was never contented...there was so much vacuum created].

These narrative accounts provide a background knowledge, in Eco's words (1979, as cited in Franzosi, 1998), an intertextual encyclopedia that makes us understand why the Anak ng OFWs would think nakasanayan na and yet recognized that in its very core was a kakulangan, an emotional narrative space. Tucker (1965) discussed Weber's concept of Verstehen, an empathetic understanding of the "other" or an understanding from within, that invites us to look within to understand why the Anak ng OFWs would think, decide and behave the way they do. We take the perspective of the narrators of their stories, the Anak ng OFWs. We clearly see the interplay of their stories, or the text, and the context, the OFW phenomenon that began with their parents' transformative decision to be OFWs and work away from their families.

\section{Conclusion}

This study defamiliarizes when it seeks a pragmatic approach and avoid the idealized view of face-to-face interaction, rather through platforms of mediated communication and online relationships, the essence of familyness is nurtured. In the defamiliarized perspective of the Filipino family, the study observed Appadurai's idea of situated difference where OFW parents' expressed not in the old habitual way but in a different, unfamiliar 
repertoire of being haligi and ilaw ng tahanan, of pag-aaruga, of being family, and remained connected with their Anak. The Anak ng OFWs recognized the efforts of their parents to be connected with them and establish meaningful familial and online relationships through the mediated platform notwithstanding depth of communication. They recognized how their OFW father was the head and main provider of the family and how their parents fulfilled their traditional roles and obligations as haligi and ilaw ng tahanan. They valued their OFW parents' pag-aaruga in the economic remittances, the balikbayan boxes, and pasalubong or gifts that provided for their needs.

The emergent narratives of the Anak ng OFWs showed the actual unfolding of the OFW family story line as it emerged in their lived realities as Anak and as they described their perspective of simply nakasanayanna-kind of family set-up with elements that were different from what was traditionally known. The essence of family-ness, that included the longing for a magkakasamang pamilya or family togetherness, and cultural values important to the family were present but expressed in after-different-thanbefore and unfamiliar ways. The Anak $n g$ OFWs exemplified the meaning shifts in family life as they created spaces for the little family in the virtual or imagined household and gratefully recognized that they were the reason for their OFW parents' departure to enable them to be providers or haligi and ilaw ng tahanan, not in the habitual, automatic and traditional manner but from an unfamiliar distance. They viewed their OFW family to be different but with its cracks and fractures taken as normal elements of a newly-created and being created configurations of the Filipino family. Pragmatically, they weaved the factors together, including their roles and responsibility as Anak, and considered their family to be ordinary, that is, nakasanayan na, and yet, simultaneously extraordinary as they anticipated the celebratory, seasonal homecoming of their OFW parents and enjoy the moments of being a magkakasamang pamilya. The core narrative for these Anak ng OFWs about their family was acceptance: nakasanayan na, and viewed their OFW parents' departure and absence as normal occurrences in their family. The narrative accounts provided background knowledge to show Verstehen, to understand how the Anak ng OFWs accepted the nakasanayan na perspective and yet showed an emotional narrative space to recognize the kakulangan at the very core of the OFW family life, the strong yearning for family togetherness, a magkakasamang pamilya.

The Filipino family had become a site of contestation where meanings are constantly negotiated. Where a family once perceived as whole only when together, this study proposes that the Filipino family can remain a nurturing family, a magkakasamang pamilya, taking utmost advantage of mediated platforms and online relationships to remain connected. It remains 
compact with its willing text-producing actors and that which carries over its cultural values and traditional practices in transnational fields. In Derrida's language, that is the way things are in this situated difference. The Filipino family continues to play its part as the bedrock of the nation as it exists in the OFW ethnoscape, but not without its own imperfections, cracks and fractures. Literature in itself, including this humble contribution, revealed consistent findings of the irreversible impact on the OFW families and the lives of Anak ng OFWs. One may argue that what happens to the OFW family may happen to any family. And yet, when an OFW parent decides to leave his family for whatever reason, how justifiable it may be, he or she renders life-changing consequences that may be regrettable for a lifetime.

The OFW phenomenon has, in a sense, deterritorialized, uprooted it from its traditional situatedness and is now reterritorialized or relocated in new, varied meaningful mediated spaces drawn by the Anak ng OFWs themselves. The OFW parents and their Anak reinscribed their sense of family-ness, in a new and different context, transforming the perspective on the family. Defamiliarization changes the trajectory of the discourse when we consider the meaning shifts in how we perceive the Filipino family. While both social actors were separated by distance and connected through mediated spaces, they wilfully created a new social reality. This new awareness, invented and is accepted so that what is familiar may be rendered anachronistic, indeed. As a matter of fact, home can be in multiple places but where ties and connection, albeit imperfect, remain. However, by all means, the yearning for magkakasamang pamilya remains, and the OFW and their Anak, as literature affirms, maintain a longing to return to their "original home." 


\section{References}

Abenir, M. A. (2010). A social protection and integration strategy for children of OFWs: A case study on the psycho-social support program of BUNGA Foundation, Inc. Philippine Journal of Social Development, Volume 2, 37-58.

Abenir, M. A. D. (2014). In their voices: The rights and capabilities of the "Anak ng OFW" [Unpublished master's thesis]. College of Social Work and Community Development, University of the Philippines, Diliman.

Aguila, A. P. N. (2008). Living long-distance relationships through computer mediated communication. Social Science Diliman, 5(1), 83-106. http://journals.upd.edu.ph/index.php/socialsciencediliman/ article/viewFile/2045/1955

Appadurai, A. (1997). Modernity at large: Cultural dimensions of globalization. University of Minnesota Press.

Asis, M. M. B. (1994). Family ties in a world without borders. Philippine Sociological Review, 42(1-4), 16-26.

Asis, M. M. B., \& Marave, C. R. (2013). Leaving a legacy: Parental migration and school outcomes among young children in the Philippines. Asian Pacific Migration Journal, 22(3), 349-376.

Bautista, A. G. M., \& Tamayo, V. T. (2020). Life challenges of Overseas Filipino Workers. Open Access Library Journal, 7(1-9). https://doi.org/10.4236/oalib.1106854

Bernardo, Allan B.I., Daganzo, Maria Angeline A., \& Tan-Mansukhani, Roseanne. (2018). Associations between materialism, gratitude, and well-being in children of overseas Filipino workers. Europe's Journal of Psychology, 14(3), 581-598. https://doi.org/10.5964/ejop.v14i3.1555

Bernarte, R. P., Datiles, J. C. M., Samson, R. T., \& Velasco, S.M, B. (2015). Reshaping communication: A study of how mediated to computer-mediated communication exchanges affects the relationship among Overseas Filipino Workers families. European Academic Research, 2(11), 14197-14220. https://www.euacademic.org/UploadArticle/1343.pdf.

Burgess, E.W. \& Locke, Harvey J. (1953). The family, from Institution to companionship (2nd ed). American Book Company.

Camposano, C. C. (2012). Balikbayan boxes and the performance of intimacy by Filipino migrant women in Hong Kong. Asian and Pacific Migration Journal, 21(1), 83-103.

Concepcion, S. B. (1998). Structures and processes of families in a labor exporting community [Unpublished doctoral dissertation]. University of the Philippines, Diliman.

Corbin, J., \& Strauss, A. (1990). Basics of qualitative research: Grounded theory, procedures and techniques. Sage Publications.

Derrida, J (1976). Of grammatology (G. C. Spivak, trans.). Johns Hopkins University Press.

Gelles, R. J. (1995). Contemporary families: A sociological view. Sage Publications, Inc.

Glaser, B. G., \& Strauss, A. L. (1967). The discovery of grounded theory: Strategies for qualitative research. Aldine Transaction.

Gunn, D. P. (1984). Making art strange: A commentary on defamiliarization. The Georgia Review, 38(1), 25-33.

Hall, B. J., Garabiles, M. R., \& Latkin, C. A. (2019). Work life, relationship, and policy determinants of health and well-being among Filipino domestic workers in China: A qualitative study. BMC Public Health, 19, 229. https://doi.org/10.1186/s12889-019-6552-4 
The Internet Encyclopedia of Philosophy. "Jacques Derrida." ISSN 2161-0002. http://www.iep.utm.edu/ derrida/

Jabines, J. T. (2018). One hour at a time. https://www.rappler.com/voices/imho/203028-philippinediaspora-ofw-one-hour-at-a-time/

Jocano, F. L. (1998). Filipino social organization: Traditional kinship and family organization. Punlad Research House.

Labov, W., and Waletzky, J. (1967). Narrative analysis: Oral versions of personal experience. In J. Helm (Ed.), Essays on the verbal and visual arts (pp. 12-44). University of Washington Press.

Liamzon, C. M. (2010). Reunification of Filipino families in Italy: What the youth have to say. Philippine Journal of Social Development, 2, 59-82.

Light, J. (2001). Separate but equal. APPA Journal, 67(3), 273-page range.

Leeds-Hurwitz, W. (2002). Wedding as text: Communicating cultural identities through ritual. Routledge. eBook.

Mambrol, N. (2016). Defamiliarization: Literary theory and criticism. https://iterariness.org/2016/03/17/ defamiliarization/

Miller, D., \& Madianou, M. (2012). Polymedia: Towards a new theory of digital media in interpersonal communication. International Journal of Cultural Studies, 16(2) 169-187. Retrieved from: https:// journals.sagepub.com/doi/full/10.1177/1367877912452486

Medina, B. T. G. (2015). The Filipino family (3rd ed.). University of the Philippines Press.

Meyrowitz, J. (1986). No sense of place: The impact of electronic media on social behavior. Oxford University Press.

Moores, S., \& Metykova, M. (2010). “I didn't realize how attached I am“: On the environmental experiences of trans-European migrants. European Journal of Cultural Studies, 13(2), 171-189.

Morley, D.. (2017). Communications and mobility: The migrant, the mobile phone, and the container box. John Wiley and Sons Ltd. / Vivar Printing Sbn Bhd.

Parreñas, R. S. (2006). Children of global migration: Transnational families and gendered woes. Ateneo de Manila University Press.

Reissman, C. K. (1993). Narrative analysis. In M. A. Huberman \& M. B. Miles (Eds.), The Qualitative researcher's companion (pp. 217-270). Sage Publications.

Reyes, M. M. (2008). Migration and Filipino children left behind: A literature review. http://www.unicef. org/philippines/Synthesis_StudyJuly12008.pdf

Resseguie, J. L. (1991). Automatization and defamiliarization in Luke 7:36-50. Literature and Theology, 5(2), 137-150.

Santos, A. P. (2015). For Filipina OFWs, missing childhoods. https://legacy.pulitzercenter.org/reporting/ filipina-ofwsmissing-childhoods

Scalabrini Migration Center. (2004). Hearts apart: Migration in the eyes of Filipino children. Scalabrini Migration Center

Segrin, C., \& Flora, J. (2019). Family communication (3rd ed.). Routledge Taylor \& Francis Group.

Sobritchea, C. I. (2007). Constructions of mothering: The experience of female Filipino overseas workers. In Teresa W. Davasahayam \& Brenda Yeo (Eds.), Gendering Asia (pp. 173-194). NUS Press. 
Tacoli, C. (1996). Migrating 'for the sake of family'?: Gender, life course and intra-household relations among the Filipino migrants in Rome. Philippine Sociological Review, 44(1-4), 12-32.

Tanalega, N. E. (2002). Families on the move. Ugat Foundation, Ateneo de Manila.

Taylor, A. R., Guss, D. C. \& Tuason, M. T. G. (2012). Experiences of adult children of transnational workers. Philippine Journal of Psychology, 45(1), 25-52.

Tucker, W. T. (1965). Max Weber's Verstehen. The Sociological Quarterly, 6 (2), 157-164.

UNICEF. (2008). Migration and Filipino children left behind: A literature review. Manila, Philippines.

Urry, J. (2007). Mobilities. Polity Press.

Wamboldt, F., \& Reiss, D. (1989).Defining a family heritage and a new relationship identity:Two central tasks in the making of a marriage. Family Process, 2, 317-335.

Wilken, R. (2011). Teletechnologies, Place and Community (1st ed.). Routledge. 


\section{Grant Support Details}

Author Contributions: All research activities and writing were done by M.J.L.Pinzon. The author has read and agreed to the published version of the manuscript.

Funding: The author acknowledges the Office of the Chancellor of the University of the Philippines Diliman, through the Office of the Vice Chancellor for Research and Development, for funding support through the Ph.D. Incentive Award

Acknowledgements: The author would like to thank all the Anak ng OFWs who participated in the study for their time and commitment, as well as her mentors who provided their valuable insights in this study.

Conflict of Interest: The author declares no conflict of interest.

\section{About the Author}

MARY JANNETTE L. PINZON, PhD. is with the faculty of Speech Communication and Theatre Arts Department of the UP College of Arts and Letters. She obtained her doctoral degree in Philippine Studies from the University of the Philippines. (Corresponding author: mlpinzon@up.edu.ph) 
